\title{
SHAKESPEARE'S TWELFTH NIGHT AS A COMEDY
}

\author{
*Appalal Abdulgaffar Attar
}

\section{Abstract}

William Shakespeare happens to be the greatest writer of the world. He is called the Bard of Avon. He is a great playwright and poet. His 37 plays include his tragedies, tragi-comedies, histories (covering Roman plays), sonnets, and comedies. The present play focuses on his fine drafting of upholding the language. The essential spirit of the play 'Twelfth Night' is captured in its title. The world of Twelfth Night is one of comedy and comic excess; and among all of the characters in the play, it is the drunken, misbehaving and prankish Sir Toby Belch who epitomizes its humorous nature. In Twelfth Night, despite the festive spirit of the play, Shakespeare invites his audience to notice certain problematic aspects of the story. Reductively, the theme of Twelfth Night is the joy and pain of love. The play was written in Shakespeare's older years and he attempts to see love for all that is both good and bad about it. This may explain why Twelfth Night has a subtitle, What You Will (the only play that has one, between). Twelfth Night explores a variety of themes and issues. The major theme of celebration and festivity was prevalent in all of the sources from which Shakespeare drew.

Keywords: Dramatic Techniques of Shakespeare, Historical Material of Shakespeare, Shakespearean Theme, Shakespearean's Doctrine of Love, Twelfth Night or What You Will is as a Comedy.

\section{Introduction}

Shakespeare's Twelfth Night or What You Will is a comedy, first performed in 1600 and published in the First Folio of 1623. The most direct source was Barnabe Riche's Apolonius and Silla, a story derived from the Italian Matteo Bandello.

Shakepeare's Twelfth Night is a lovely romantic comedy. Shakespeare made use of the other historical literary materials such as Il Sacrificio (1537), Charles Estienne's Les Abuses (1543), Nicolo Secchi's GiIanganni (1562), Lope de Rueda's Los Enganos (1556), Geraldi Cinthio's Hecatommithi (1565), Belleforest's Histories Traqiques (1570), Barnabe Riche's Riche His Farewell, and Curzio Conzaga's GiInganni (1592).

Shakespeare's Twelfth Night has the main plot concerning the Italian twins Viola and Sabastian, getting shipwrecked, and marrying honorable people from royal places. The sub-plot, equally interesting relates to a marriage of the people around Olivia. The main story was not totally new in Shakespeare's times. It was reflected in the Greek work of the Menaechmi of Plautus, and a thread of it was reproduced in The Comedy of Errors and the fable so often met within early fiction writers, that namely, of a woman in disguise as a page who falls in love with her master, yet pleads his cause with another woman, who in turn falls in love with her. Shakespeare's play The Two Gentlemen of Verona has an instance of this, and the same motif is used in The Merchant of Venice.

The work of G' Ingannati was a chief inspiration for Shakespeare. The Italian name Malveleo was changed to Malvolio. Shakespeare got the concept of 'twelfth night' there. Shakespeare got an idea for the under-plot there. Perhaps he got the name Sir Toby and Fabio assumed by Lelia in her disguise. A certain scholar Hunter did this discovery. It is said: Feb. 2. At our feast wee had a play called 'Twelue Night, or What You Will,' much like The Commedy of Errores, or Menechnmi in Plautus, but most like and neere to that in Italian called Inganni. A good practice in it to make the steward believe his Lady widow was in love with him, by counterfeiting a letter as from his Lady in general terms, telling him what she liked best in him, and prescribing his gesture in smiling, his apparaile, etc., and then when he came to practice making him beleeue they tooke him to be mad. ${ }^{1}$

The original name for the lady in disguise was Cesare, which Shakespeare used as Cesario. 
Morton Luce adds:

The story as told by Bandello was almost certainly in Shakespeare's hands, and as certainly the French version is Belleforest. As to the "Apolonius and Silla' of Barnabe Riche, it was the least suggestive of all these originals to which Shakespeare had access; indeed it is poor stuff, and merited if it did not receive the poet's contempt Cinthio and the Spanish plays he may have consulted; also the Latin version, "Laelia"; and there is a passage in the second book of Sir Philip Sidney's "Arcadia" (1599), which he must have read, where a woman disguised as a page follows her master to the death. Nor have we exhausted the list of authors who made literary capital of these or similar incidents. ${ }^{2}$

The play's name Twelfth Night refers to a Christian festival. The sub-title 'What You Will' sounds like 'As You Like it' as the name of another of Shakespeare's famous comedy. The date of the play is 1601. Shakespeare copied the names from Forde's "Parismus" (1598). In 1599 Morley's 'Consort Lessons' which had the song "O Mistress mine" appeared. Ben Jonson referred to the name 'Twelfth Night' in his comedy "Every Man out of his Humour" (1599). In brief Shakespeare's play was written in 1600 .

The time analysis of the play is: $1^{\text {st }}$ day, I. i-iii, Interval of three days. $2^{\text {nd }}$ day, I. iv., v.; II. i-iii, $3^{\text {rd }}$ day, II. iv., v.; III. IV, V.

Morton Luce observes that:

'Twelfth Night' is referred to for illustrations of Shakespeare's doctrine of love, his religious views, and his political opinions. Here we may add concerning the play generally, that it is the comedy of comedies; not only are the elements of comic drama and comic satire from Plautus to Rabelais herein represented as fully and as perfectly as may be, for the comedy of "Twelfth Night" is both relieved and heightened by an interwoven exquisite romance, while strains of the finest poetry make perfect harmony with the comic undertone. Further, the play is splendidly wrought; plot, underplot, incident, character, movement, dialogue, diction, each is excellent; and our interest is sustained throughout at the highest dramatic level. Finally, a gay good humour is the all-pervading spirit of the drama; its gentle satire is wholesome, not bitter. ${ }^{3}$

Shakespeare's Twelfth Night is a lovely comedy. It takes place in Illyria, on the shores of the Adriatic Sea, a land of sunlight and laughter and the most beguiling poetry, where no real harm can come to anyone and nothing is damaged. The play is very much like the festival for which it was named, the twelfth night that comes as a climax to the
Christmas holidays when the working world is forgotten in the delight of make-believe.

The story opens in the palace of the duke of Illyria. The object of his affections is a beautiful lady named Olivia, who is mourning the death of her brother.

On the seacoast of Illyria there has been a violent storm, and another lovely lady comes ashore after a shipwreck to mourn a brother she believes to be lost at sea. This lady is Viola, a lively of Shakespeare's heroines, and when she hears of the lovesick duke she decides to disguise herself and become his page.

The household of Olivia is not as grave as it ought to be. For her uncle is staying with her, a fat and cheery old reveler named Sir Toby Belch. He has personally chosen a suitor for his niece in the person of Sir Andrew Aguecheek, a weak knight who knows he is a fool. Sir Toby and Sir Andrew have been sitting up until all hours getting drunk, and Olivia sends her waiting-woman, Maria, to see that they stop it. Sir Toby maintains that he has merely been drinking his niece's health, and he and Sir Andrew end the scene by comparing notes on their dancing. Sir, Andrew does not like to boast, but he feels he is a fine fellow. 'I think I have the back-trick simply as strong as any man in Illyria.' Other-wise, the knight is feeling a little discouraged as he doubts Olivia's intention.

Likewise, The duke of Illyria, has decided to send his new page to woo Olivia for him. The page is Viola, very charming in her boy's attire. Viola promises she will do her best, but her heart is not in it, for she has fallen in love with the duke.

Olivia's household is not an especially orderly one, and her jester Feste has been absent without leave. Maria assures him he will be hanged for staying away. After all, "a good hanging prevents a bad marriage.” He knows he is safe with his mistress.

Malvolio is the manager of Olivia's household. He struts with a lordly gait, completely surrounded with the splendor of his own self-importance. He says so once too often, and his mistress tells him exactly what is wrong with him. "You are sick of self-love, Malvolio .... To be generous, guiltless, and of free disposition, is to take those things for bird-bolts that you deem cannon-bullets."

Sir Toby comes in, well fuddled after a night's drinking and blaming it all on the pickled herring. He says there is a young gentleman at the gate. 
Viola is a young gentleman having come to woo the duke and describing him in full. Olivia suggests that she shorten it. Viola tells,

Make me a willow cabin at your gate,

And call upon my soul within the house;

Write loyal cantons of contemned love,

And sing them loud even in the dead of night;

Holla your name to the reverberate hills,

And make the babbling gossip of the air

Cry out 'Olivia!'

Olivia does not fall in love with the duke, however, but with his lively and persuasive page, and when Viola leaves she sends Malvolio after her with a ring.

Meanwhile, Sebastian, Viola's brother arrives in Illyria, together with the man who rescued him from the sea.

It is after midnight in Olivia's house, and Sir Toby Belch is having a splendid time, for he is threequarters drunk. He is in the mood for loud and vigorous song, and Feste and Sir Andrew are encouraging him. Malvolio enters, full of outraged dignity. As Sir Toby says, "Dost thou think, because thou art virtuous, there shall be no more cakes and ale?" Even Maria, who has been trying to quiet the three revelers herself, finally takes their part against Malvolio and shouts after his departing back, "Go shake your ears."

Maria is really annoyed with Malvolio. She has had enough of his conscious rectitude and she decides to play a trick on him.

The duke meanwhile is passing the time by listening to an old song that tells of 'the innocence of love' and by describing his emotions at length to his charming page. Viola listens to him intently.

Maria composes her letter and seals it with Olivia's seal, and then she drops it casually near the garden walk. Sir Toby and Sir Andrew hide behind a tree, along with another member of the household named Fabian. The three of them watch Malvolio, their enemy come sauntering along. Malvolio is absorbed in his favourite daydream, in which he sees himself married to Olivia, ordering her servants about. The indignant Sir Toby nearly explodes out of his hiding place, but he is rewarded when Malvolio picks up the letter.

Maria has done her work. It is just the kind of letter a woman in love with her steward might write, adoring. "I am above thee, but be not afraid of greatness. Some are born great, some achieve greatness, and some have greatness thrust upon them." These lines are aphoristic, no doubt. It continues with advice on how best to pleasure her.
Let him smile. "In my presence still smile, dear my sweet." And let him wear yellow stockings and his garters crossed, for such a costume is most pleasing to her.

Malvolio at last sees his dream coming true. "I will be strange, stout, in yellow stockings and crossgartered, even with the swiftness of putting on." Practically married to Olivia already, he surges offstage, leaving Maria to stare after him. What happens then, in Maria's opinion, will be worth seeing.

Viola is again sent by the duke to plead his suit, and this time Olivia receives her. It is clear to all the household that she is in love with the charming page, and Sir Andrew Aguecheek is outraged. He hopes to marry Olivia himself and has been lending money lavishly to Sir Toby. Sir Toby points out that he should have come forward. Since he has failed in this, nothing remains but to challenge the page to a duel- an appalling project for anyone as cowardly as Sir Andrew.

Viola's brother, in the meantime, has been walking about town as a tourist. The friend who saved him from shipwreck cannot accompany him, since he has the reputation in Illyria of being a pirate.

Olivia is in a melancholy mood because the page does not return her love, and she decides that the solemn and dignified Malvolio will be a suitable companion for her state of mind. She sends for him and he enters and greets her in what he feels is an appropriate manner: "Sweet lady, ho, ho." $\mathrm{He}$ prances merrily about, refers knowingly to the letter, and calls Olivia sweetheart that convinces her she is dealing with a lunatic. Since Olivia is a kindhearted woman, she leaves him to the care of Sir Toby, who treats Malvolio as if he were a demented infant.

Also in trouble is Sir Andrew Agueecheek, who has finally resolved to fight a duel with the duke's page. Sir Toby sends him off to the orchard to look for Viola, and as soon as she arrives at the house kindly informs her that Sir Andrew is breathing fire. "He is a devil in private brawl... and his incensement at this moment is so implacable, that satisfaction can be none but by pangs of death and sepulcher."

Viola has often found her boy's disguise to be an inconvenience, but never more so than at this moment. She hardly knows one end of a sword from the other. Sir Andrew, equally terrified, is hopefully considering the offer of his horse as a bribe if the duke's page will refuse to fight with him. But the two reluctant duelists are finally persuaded into facing each other. 
At this point Sebastian's friend enters and mistakes Viola for her twin brother. He attempts to interfere with the duel and is arrested by the duke's officers. He implores Viola to give him back the money he lent her but she does not know what he is talking about. He is led away by the duke's officers, and then Viola, thinking over what he has said, begins to suspect that her brother is alive.

Sir Andrew can see that the page is a coward. He tells, "I'll beat him." But unfortunately for him it is Viola's brother he encounters, a vigorous young man who bangs him. Sir Andrew is deeply shocked by such behavior. "I'll have an action of battery against him if there is any law in Illyria. Though I struck him first, yet it's no matter for that." Olivia hears the commotion and asks Sebastian, who she thinks is the page, to come with her to be married; and Sebastian, bewildered but delighted, agrees. The two natural people marry.

Malvolio has been tied up in the dark to calm his scattered wits, with Feste disguised as a person to visit the lunatic. Feste is very fond of money, and Malvolio finally bribes him into bringing ink and paper so that he can write a letter to Olivia.

Viola finds herself in a series of predicaments. Sebastian's friend accuses her of ingratitude in refusing to give him back his money; Olivia announces she has just married Viola; and Sir Andrew Aguecheek accuses Viola of breaking his head. They have all mistaken her for Sebastian, whose entrance solves the whole problem. The delighted Viola is able to welcome the lost brother she believed to be drowned, and the duke realizes that she is the one he really loves.

Everyone is happy except Malvolio. Fabian pleads that it was only a joke, but Malvolio will not forgive such an insult. "I'll be revenged on the whole pack of you." He stalks out, an enemy of laughter to the end, and the duke, who wants no one to be unhappy, sends a peacemaker after him.

For no one should be angry in Illyria, and the play closes in joyfulness and a final song.

\section{Twelfth Night Key Themes}

- In Twelfth Night, despite the festive spirit of the play, Shakespeare invites his audience to notice certain problematic aspects of the story.

- The comic elements in this play include moments of mistaken identity, comic wordplay, and the prank played on the pompous Malvolio.

- Love in Twelfth Night is irrational and fickle, as shown in the Duke's quick transition from fervently wooing Olivia to falling in love with Viola.
Love is also associated with madness: Malvolio's love for Olivia leads to his imprisonment for lunacy. Twelfth Night discovers a diversity of themes and issues. The major theme of celebration and festivity was prevalent in all of the sources from which Shakespeare drew. Critics have explored the impact of this theme on the play's events as well as the limitations of celebration. The conflict between appearance and reality is brought to the fore by die elements of role-playing and disguise. Additionally, the use of language to deceive as well as the failure of characters to communicate effectively or truthfully are also issues studied and debated among critics and students of the play.

Twelfth Night has some slight defects, especially of dramatic technique; the duration of the action is hard to determine; the marriage of Sebastian seems forced and hurried; that of Sir Toby and Maria is ill defined; the sequence of Act and Scene is hard to follow. Some will add that there is lack of characterization. But we are not greatly troubled by these spots.

\section{References}

1. The Serious Comedy of Twelfth Night: Dark Didacticism in Illyria; By Marciano, Lisa Renascence: Essays on Values in Literature, Vol. 56, No. 1, Fall 2003

2. Speech and Performance in Shakespeare's Sonnets and Plays; By David Schalkwyk Cambridge University Press, 2002

3. Luce, Morton. Handbook to Shakespeare's Works. New Delhi: Goodwill, 1960. p.250.

4. William Shakespeare's Twelfth Night; By Harold Bloom

5. Luce, Morton. Handbook to Shakespeare's Works. p.251.

6. As She Likes It: Shakespeare's Unruly Women; By Penny Gay Routledge, 1994: Chap. 2 "Embodiment: The Sonnets, Love's Labour's Lost, Romeo and Juliet, and Twelfth Night"

7. Shakespeare's Brain: Reading with Cognitive Theory; By Mary Thomas Crane Princeton University Press, 2001: Chap. 3 "Twelfth Night: Suitable Suits and the Cognitive Space Between"

8. Luce, Morton. Handbook to Shakespeare's Works. p.252.

9. All the textual references are to Shakespeare's play Twelfth Night.

10. Shakespeare's Twelfth Night: Or, What You Will ; By William Shakespeare; William Allan Neilson Scott Foresman, 1903

11. The First Night of Twelfth Night; By Leslie Hotson Macmillan, 1954 
12. Shakespeare the Playwright: A Companion to the Complete Tragedies, Histories, Comedies, and Romances; By Victor L. Cahn

13. Shakespeare and the Poets' War; By James P. Bednarz Columbia University Press,
2000: Chap. 7 "Shakespeare at the Fountain of Self-Love: Twelfth Night at the Center of the Poets' War". 